\title{
KONTRASTIIVINEN ANALYYSI, TRANSFER JA TOISEN KIELEN OPPIMINEN
}

\author{
Kari Sajavaara \\ Soveltavana kielentutkimuksen keskus \\ Jyväskylän yliopisto
}

Lähivertailuja 17.

Toimittaneet Annekatrin Kaivapalu, Külvi Pruuli.

Jyväskylä Studies in Humanities, 53.

Jyväskylä: Jyväskylän yliopisto, 2006, pp. 9-25.

ISBN 951-39-2450-5

ISSN 1459-4323 


\section{Lähtökohdat}

Valtaosa vieraan kielen aikuisopiskelijoista on hyvin tietoisia siitä, että äidinkieli kummittelee tavalla tai toisella, joskus enemmän, joskus vähemmän, opittavan kielen tuottamisessa ja tuotoksissa. Aika merkillisenä voidaan siksi pitää sitä, että toisen kielen oppimista koskevassa teoreettisessa ajattelussa ja tutkimuksessa oli pitkä vaihe 1980- ja 1990-luvulla, jolloin monet tutkijat lähes kokonaan kielsivät äidinkielen ja myöhemmin omaksuttujen kielten välisen vuorovaikutuksen olemassaolon. Toisen kielen oppimisen ja kaksikielisyyden tutkimuksen varhaisvaiheissa 1940-luvulla ja 1950-luvulla uusi kieli oli nähty ikään kuin suodattuneena äidinkielen läpi.

Kontrastiivisen kielentutkimuksen nousu 1950-luvulla toisen kielen oppimisen ensimmäiseksi teoreettiseksi viitekehykseksi oli luonnollinen seuraus siitä, millaiseksi oppiminen tuolloin hahmotettiin (Sajavaara 1977, 1999). Elettiin behaviorismin valtakautta. Oppiminen oli tulosta ärsykkeitä seuraavien reaktioiden toistamisesta. Tässä viitekehyksessä oli itsestään selvää, että se, mitä äidinkielessä oli opittu, oli vaikuttamassa muita kieliä myöhemmin opiskeltaessa. Näkökulma kieleen oli strukturalistinen. Kun behaviorismi ja strukturalismi laskettiin yhteen, ongelmat toisen kielen oppimisessa näkyivät ensisijaisesti äidinkielen rakenteiden ilmenemisessä opittavan kielen rakenteiden sijasta. Kiinnostus kohdistui ensisijaisesti siihen, millaisia poikkeamia äidinkieli tuotti kohdekielessä. Äidinkielen myönteisen vaikutuksen mahdollisuudesta ei sen sijaan puhuttu. Luonnollinen selitys oli se, että kielenopetuksen tärkeimpiä tehtäviä oli virheiden karsiminen oppijan kielenkäytöstä.

Aiemmin opitun vaikutusta myöhempään oppimiseen alettiin kuvata nimityksellä transfer, joka on suomennettu siirtovaikutukseksi. Oppijoiden ajateltiin siirtävän oman kielen ja kulttuurin muodot ja merkitykset uuteen kieleen sitä tuottaessaan. Kielen ymmärtämisessä esiin tulevia vastaavia ilmiöitä ei ollenkaan käsitelty, vaikka myönteinenkin transfer yleensä tuli mainituksi. Transferin kielteisiä seuraamuksia alettiin kutsua interferenssiksi. Huomattava on, että siirtovaikutus sinänsä ei ole kielteistä eikä myönteistä, vaan ainoastaan sen lopputulosta voidaan pitää kohdekielen kannalta myönteisenä tai kielteisenä. 
Kokonaan huomiotta jäi myöhemmin huomattavasti huomiota saaneet havainnot myöhemmin opittujen kielten vaikutuksesta aiemmin opittuihin.

Varhaiset pyrkimykset kielten kontrastoimiseen liittyivät suoraan haluun tuottaa kielitieteellisesti perusteltua aineistoa kielenopetuksen tarpeisiin. Kielenopetuksen arveltiin hyötyvän ratkaisevasti siitä, että käytettävissä olisi oppijan oman kielen ja opetuksen kohteena olevan kielen tieteellisten kuvausten huolellinen vertailu. Tällaisen ajatuksen toi ensimmäisenä esiin Fries (1945: 9), joka oli Yhdysvalloissa audiolingvaalisen kielenopetusmenetelmän alullepanija. Vahva tuki kieliä vertailevalle näkökulmalle tuli myös kaksikielisyystutkimuksen klassikoiden Weinreichin (1953) ja Haugenin (1953) taholta. Weinreichin mukaan esimerkiksi kaksikielisten puheessa käytössä olevan kielen normeista esiintyvät poikkeamat johtuvat siitä, että kaksikielisillä on hallussaan useampia kieliä kuin yksi.

Voimakkaimmat virikkeensä kontrastiivinen kielten vertailu sai Friesin kollegan Robert Ladon kirjasta Linguistics Across Cultures (1957). Ladon mukaan kielten väliset eroavuudet ja kielenoppimisen vaikeus olivat keskenään suoraan verrannollisia. Esipuheessaan hän toteaa, että "voimme ennustaa ja kuvata ne järjestelmät, jotka aiheuttavat ongelmia, ja ne, jotka eivät aiheuta ongelmia, vertaamalla systemaattisesti opittavaa kieltä ja kulttuuria opiskelijan äidinkieleen ja kulttuuriin".

Yhdysvalloissa 1950-luvun lopulla voimakkaasti virinnyt kontrastiivinen tutkimus tukahtui 1960-luvulla, kun sen tulokset eivät näyttäneet tuottavan toivottuja aineksia kielenopetuksen tarpeisiin, ja samoihin aikoihin behaviorismi ja strukturalismi korvautuivat kognitiivisella oppimisteorialla ja generatiivisella kielikäsityksellä. Behavioristiseen oppimiskäsitykseen pohjannut transfer sai samalla myös mennä. Toisen kielen oppimisen tutkimuksessa korostuivat tässä vaiheessa lähinnä luonnollisessa kielenkäyttöympäristössä toista kieltä oppineilta tehdyt havainnot, jotka osoittivat ykköskielen vaikutusta olevan toisen kielen käyttäjillä hyvin vähän. Vieraan kielen oppijoilta virheanalyysin tarpeisiin saadut aineistot sen sijaan viittasivat samanaikaisesti hyvinkin vahvaan ykköskielen vaikutukseen.

Tilanne muuttui vähitellen 1990-luvulla, osittain myös siksi, että chomskylaisen kognitiivisen teoretisoinnin rinnalle nousi suuri joukko uusia tapoja tarkastella kieltenvälistä vuorovaikutusta. Ajattelu muuttui ratkaisevasti siinä vaiheessa, kun yleisesti alettiin myöntää kielenkäyttäjän kaikkien kielten olevan vuorovaikutussuhteessa toisiinsa, ei vain ensikielen vaikuttavan myöhempiin, vaan myöhempien kielten vaikuttavan myös ensi kieleen (esim. Pavlenko \& Jarvis 2002). Monelta kannalta tätä on pohtinut Cook (1995) eritellessään käsitettä, jota hän kutsuu monikieliseksi kompetenssiksi (multicompetence). Myös kolmannen kielen asemaa transferin kohteena on tarkasteltu laajasti (Cenoz et al. 2001). Oppijan ensi kielessä tapahtuu myös muutoksia uusien kielten oppimisen vaikutuksesta.

Kontrastiivisen analyysin kritiikissä esiintyi myös laajalti jokseenkin kapea näkemys siitä, mitä kieli on, mikä on tärkeää, jotta ihmiset voivat kommunikoida keskenään kielen avulla, ja erityisesti, kuinka toisia ja vieraita kieliä 
opitaan. Näkökulma kieleen oli keskeisesti analyyttinen, ja pohdiskelussa korostuivat ratkaisevalla tavalla muodolliset kieliopilliset seikat. Ajattelussa oltiin luonnollisesti kytköksissä oman aikakauden käsityksiin siitä, miten kieliä opitaan ja miten niitä siksi myös pitäisi opettaa. Kielen 'osataitojen' oppimisen oletettiin olevan välttämätön edellytys, jotta kielen hallinta erilaisissa kielenkäyttötilanteissa tulisi mahdolliseksi. Vaikutusvaltaiset uusimmat teoriat kyllä tarkastelevat toisen kielen oppimista tuloksena merkitysneuvotteluista ja kielisidonnaisten tehtävien toimittamisesta, mutta nekään eivät ole vapaita kielentutkimukselle tyypillisestä taipumuksesta yksinkertaistaa ja standardisoida (Block 2002: 121-124).

Sikäli kun tarkoituksena on kielten rinnakkainen tarkastelu kielenoppimisen ja kielenopetuksen tarpeisiin, pelkkä kielen rakenteiden vertailu riitä, vaan tarvitaan monitahoisempaa näkemystä siitä, millaiset tekijät ovat vaikuttamassa oppimistapahtumaan missäkin oppimisen vaiheessa ja missäkin oppimisympäristössä. Tuoreet sosiokulttuuriset pohdiskelut kielen oppimisesta ovat tuoneet uudenlaista ajattelua kielenoppimisen tarkasteluun (Lantolf 2000, van Lier 1996). Samaan suuntaan ohjaavat toisaalla kielikoulutuksen kokonaisuutta hahmottavat selvitykset, kuten esimerkiksi yhteinen eurooppalainen viitekehys (2003) ja eurooppalainen kielisalkku. Niissäkin yhteyksissä on kielten keskinäisestä suhteesta syytä muistaa, ettei se suinkaan ole vakio, vaan muuttuu tilanteen mukana.

\section{Kontrastiivinen analyysi}

Kontrastiivisen tutkimuksen ympärillä esiintynyt hämminki ja kovin ristiriitaiset näkemykset aiheutuivat ratkaisevasti siitä, että puhtaasti teoreettiseksi katsottavan kielten vertailun odotettiin antavan tulokseksi aineistoa, jota voitaisiin käyttää hyväksi kielenopetuksessa. Tärkeän eron teoreettisen ja soveltavan kontrastiivisen tutkimuksen välillä osoitti ensimmäisenä Fisiak (1971; ks. myös Sajavaara 1977), joka korosti sitä, että teoreettisesti suuntautuneessa analyysissa kieliä verrataan keskenään ilman kielten ulkopuolelta haettuja tavoitteita sellaisen tiedon saamiseksi kielistä, jollaista ei ehkä muuten saataisi. Tulokset voivat olla sovellettavissa käytännön tarpeisiin, esimerkiksi kielenopetukseen tai kääntämiseen. Teoreettista kontrastiivista analyysia voidaan harjoittaa oikeastaan millä kielen tai kulttuurin osa-alueella tahansa (äänteet ja äännejärjestelmät, muodot, syntaksi, pragmatiikka, retoriikka, tekstit), kunhan ei aseteta vaateita sovelluksista. Teoreettinen analyysi voi olla merkittävä avaus uusiin teoreettisiin näkökulmiin, ja avata uudenlaisia näkökulmia yksittäisten kielten tutkimukseen.

Soveltava kontrastiivinen tutkimus sen sijaan pyrkii tavoitteisiin, jotka ovat verrattavien kielten ulkopuolella, ja lähtee liikkeelle sovellustarpeista. Kun teoreettinen analyysi perustuu kielten samalta pohjalta lähteviin kuvauksiin (Sajavaara 1999: 110), soveltava edellyttää sellaisten metodien käyttöä, joilla 
päästään käsiksi sovelluskohteisiin, siis esimerkiksi kielenoppijan ongelmiin. On ehdottomasti muistettava, että toisen kielen oppimisen ongelmista vain osa on kielten eroista johtuvia. Kontrastiivisuuden näkökulmasta kielen oppimisen tutkimuksen perusongelma on kysymys siitä, millä menetelmillä saadaan esille sellaiset ongelmat, joita oppijoilla todellisuudessa esiintyy, ja mikä niissä on kielten välisen vuorovaikutuksen osuus. Kielenoppija itse on joka tapauksessa oppimisen agentti, ja siksi kontrastiivisuus sijaitsee oppijan mielessä, mitä se merkinneekin, eikä siis verrattavien kielten struktuureissa. Kielten järjestelmiin kuuluvat ilmiöt suodattuvat kaksikielisen kielenkäyttäjän mielen läpi. Kontrastiivisuuden psykolingvististä pohjaa ei ole kovinkaan usein yritetty edes harkita (ks. kuitenkin Kühlwein 1990; Sajavaara 1987, 1999: 120-123). On muistettava, ettei kielenoppijan tavoitteena ole kielen muotojen ja rakenteiden oppiminen, vaan oppiminen ymmärtämään ja tuottamaan merkityksiä, kuten Halliday (1975, ks. myös 1993) jo hyvin varhain osoitti. Käsitteiden merkitykseen kielen oppimisessa viittaavat myös monien uudempien tutkimusten tulokset (esim. Pavlenko 1999).

Avainkysymys kielten kontrastoinnissa on, mitä ylipäätään on soveliasta verrata keskenään (Sajavaara 1999: 110-113). Missä määrin samannäköiset tai samannimiset ainekset eri kielten järjestelmissä ovat verrattavissa toisiinsa? Esimerkiksi englannissa ja ranskassa on nominilausekkeen alkuun sijoittuvia artikkeleita, mutta mielekäs vertailu ontuu pian siksi, että kielten artikkelijärjestelmät perustuvat kovin erilaiseen määräisyyden ja spesifisyyden hahmotukseen. Näiden kielten artikkeleita ei voi oikeastaan pitää funktionaalisesti edes samana kategoriana. Suomeen verrattaessa artikkelit muuntuvat vieläkin ongelmallisemmiksi, koska suomen kielen kuvauksista ei varsinaista artikkelikategoriaa löydy ollenkaan (ks. kuitenkin Hakulinen ym. 2004: 1352 ja seur.). Vastaava merkitys piileksii suomessa monissa paikoissa, kuten esimerkiksi sanajärjestyksessä (vrt. poika oli siellä; siellä oli poika). Germaanisten kielten ja suomen kielen passiivien ero taas on malliesimerkki siitä, miten kielioppien terminologia johtaa harhaan. Suomen passiivi kattaa vain osan englannin passiivin tehtävistä silloin, kun englannissa ei osoiteta tekijää prepositioilmauksella. Kielet myös jakavat ulkopuolisen maailman ilmiöt kielen yksikköihin eri tavalla. Missä on tuleva aika lauseessa Poika kirjoittaa kirjan? Suomen preesens ei yksin edustakaan tiettyä ajan merkityskategoriaa, vaan siihen tarvitaan jatkeeksi objektin muoto, ja lisäksi ero häviää kielteisissä lauseissa. Sanastot ovat täynnään toinen toistaan monimutkaisempia asetelmia (esim. Sjöholm 1995; Jarvis 2000). Sosiaalisten käytänteiden havainnointi saattaa olla vielä kielen yksiköitäkin ongelmallisempaa, kuten keskustelu siitä, onko Suomessa small talkia, hyvin osoittaa.

Pelkkä muoto on siis useimmiten riittämätön vertailun perusta, vaan tarvitaan jokin syvemmällä oleva tarkoite tai merkitys, jota käytetään vertailupohjana. Siitä käytetään usein latinankielistä nimitystä tertium comparationis, ja kielten ilmiöiden vastaavuus voidaan paikantaa tämän 'kolmannen pyörän' kautta, sikäli kun merkitys nyt ylipäätään on 'paikannettavissa' joihinkin konkreettisesti osoitettavissa oleviin kielen yksiköihin. 
Kielten aito kontrastiivisuus toteutuu kaksikielisen kielenkäyttäjän kognitiivisessa järjestelmässä, jossa se on kieleen liittyvien ja muiden prosessien tuote. Se ei ole siis kielen struktuureissa sinänsä, vaan siinä, miten kukin kielenkäyttäjä 'kokee' kyseiset struktuurit ja tietysti käyttää niitä. Kielellisiä merkkejä ei siis oikeastaan ole tässä mielessä olemassakaan, ennen kuin ne 'syntyvät' kielenkäyttäjässä sanoman tulkinnassa tai sanomaa tuotettaessa (Sajavaara 1981). Samalla tavalla kielten väliset eroavuudet ja samankaltaisuudet ovat vaikuttamassa silloin, kun ihminen oppii toista kieltä ykköskielensä ja aiemmin opittujen kielten jälkeen.

\section{Transfer}

Käytettävissä on erilaisia teorioita ja oletuksia siitä, missä muodossa kaksi- tai useampikielisten ihmisten kielet ovat järjestelmässä, joka ohjaa kielen käyttöä ja kielten oppimista (Bialystok 2001: 106-20; Cook 1995; de Bot et al. 2005: 39-50). Ovatko kaksikielisen kaksi kieltä ikään kuin kahdessa erillisessä säiliössä vai onko olemassa vain yksi säiliö, jossa molemmat kielet sijaitsevat. Olennaista tietysti on, millä tavalla järjestelmä toimii, siis tuottaa ja vastaanottaa kieltä, eikä suinkaan, millaista metaforaa meiltä piilossa olevasta järjestelmästä käytetään. Olemassa oleva tieto siitä, mitä kahta tai useampaa kieltä käyttävien ihmisten kielenkäytössä tapahtuu, näyttäisi olevan tulkittavissa kumpaan suuntaan tahansa. On tietysti myös mahdollista, että kielten välinen suhde ei suinkaan ole samanlainen läpi koko kielten kokonaisuuden, vaan vuorovaikutus kielten kesken on kielijärjestelmän eri osissa. Siis esimerkiksi sanasto saattaa käyttäytyä eri tavalla kuin syntaksi. Lisäksi kielten suhde on kielen vastaanottamisessa selvästi erilainen kuin se on kielen tuottamisessa. Kielen vastaanottamisessa suomalaisen vaikeudet englannin kielessä alkavat jo siitä, että hän on omassa kielessään tottunut kiinnittämään kieltä havainnoidessaan kokonaan toisenlaisiin ilmiöihin ja segmentoimaan kieltä eri tavoin. Voi tietysti olla myös niin, että kielten hallinnan eri tasoilla kielten keskinäiset suhteet ovat erilaiset.

Osin kielten vuorovaikutuksen hahmottamisessa kysymys on myös siitä, millainen on kielten psykolingvistinen todellisuus: ovatko kielet ihmismielessä samannäköisiä kuin ne ovat kielistä tehdyissä kuvauksissa tai kuuluvat ja näkyvät puheessa ja kirjoituksessa valmiiksi tuotettuina? Tästäkin voidaan ainoastaan tehdä oletuksia ja rakentaa oletusten pohjalta erilaisia metaforia.

Transferiin liittyvien ongelmien hahmottamista vaikeuttaa vielä lisäksi se, että näkemykset siitä, mistä oikeastaan on kysymys, vaihtelevat sen mukaan, miten asianomainen ilmiön tarkastelija hahmottaa teoreettisesti toisen kielen oppimisen. Esimerkiksi ymmärretäänkö kielen oppimisen taustalla aina olevan jonkinlainen universaali ilmiöperusta. Aivan erilaiseksi näkökulma muuttuu esimerkiksi MacWhinneyn ja Batesin (1989) kilpailumallissa. Kielenopetuksen vaikutus voi olla merkittävä sikäli, että opetus ohjaa kielenoppijat ymmärtämään tietyt kielen kategoriat ja ilmiöt psykologisesti tosina, vaikka tämä ei pi- 
täisikään paikkaansa kielenoppijan kognitiivisessa järjestelmässä (Sajavaara 1986). Äidinkielen vaikutus tuntuu jokaisen muodollisessa opetuksessa kieltä oppineen mielessä myös siksi, että luonteva kielenkäyttö edellyttää laajaa ja aktiivista kosketusta luonnolliseen kieleen vuorovaikutustilanteissa, eikä sellaiseen oppijalla useinkaan ole mahdollisuutta. Kokemuksen puute tuntuu epävarmuutena siitä, miten tulisi toimia, ja lisää turvautumista aiemmin opittuun kieleen. Toisaalta kielenopetus voi myös vaikuttaa oppijan huomion kiinnittymiseen joihinkin tiettyihin kielen ilmiöihin, joiden merkitystä opetuksessa korostetaan, ja siten kontrastiivinen metalingvistinen kielen havainnointi voi auttaa vaikeiden rakenteiden tuottamisessa. Yleisemmin tämä taas liittyy kysymykseen, millainen asema metalingvistisellä tietoisuudella on kielen tuottamisessa. Opetusympäristössä on havaittu, että kontrastiivinen metalingvistinen tieto auttaa oppilaita siirtymään eteenpäin hankaluutta aiheuttaneissa kielen omaksumisen vaiheissa (Kupferberg 1999; Spada \& Lightbown 1999). On myös ilmeistä, ettei metalingvistinen tarkastelu voi tukea kaikkea kakkoskielen kehitystä, koska on olemassa ilmiöitä, jotka on omaksuttava. Tietoinen opiskelu voi toimia kielen inputia vahvistavana tuomalla korostetusti esiin ykköskielestä poikkeavia opittavan kielen ilmiöitä ja osoittamalla ykköskielen aiheuttamia tyypillisiä poikkeamia opittavan kielen ominaisuuksista. Metalingvistisen tietoisuuden merkityksestä seuraa, että esimerkiksi kielten luokkaopetuksessa saattaa aiemmin omaksutun kielellisen tiedon aktivoinnista olla huomattavaa etua oppijoille (Jessner 1999).

Erilaiset kielet ovat vuorovaikutuksessa erilaisessa asemassa. Läheisten sukulaiskielten kesken esiintyy siirtymiä erilaisissa yhteyksissä kuin toisistaan geneettisesti kaukana sijaitsevien kielten kesken (Ringbom 1987). Kielten välisellä etäisyydellä on siis merkitystä. Transferia esiintyy kaikilla kielen ja kielen käyttämisen alueilla äänteistä ja paralingvistisistä ilmiöistä diskursseihin ja kulttuuriseen käyttäytymiseen. Jossakin, kuten esimerkiksi morfologiassa, ykköskielen vaikutus saattaa olla vähäinen, mutta toisaalla, kuten äänteiden ja paralingvististen ilmiöiden alueella, ykköskielen vaikutus on yleensä aivan ilmeinen. Mittavimman luettelon tavoista, joilla transfer voi näyttäytyä kielessä, on esittänyt Dechert (1986). Luettelossa on 18 erilaista aluetta, missä transferia voidaan havaita. Kieltenvälistä vuorovaikutusta käsitellään myös useissa monografioissa ja artikkelikokoelmissa (Kellerman \& Sharwood Smith (toim.) 1986; Odlin 1989 ja Gass \& Selinker (toim.) 1992).

Selvää yksimielisyyttä ei tutkijoiden keskuudessa ole ollut siitä, millaisesta ilmiöstä oikeastaan transferissa on kysymys ja millaiset kahden kielen vuorovaikutuksen muodot siihen pitäisi sisällyttää. Esimerkiksi Jarvis (2000) vaatii, että transferin tutkimiseen pitäisi omaksua yksi yhtenäinen viitekehys. Vaikuttavien ilmiöiden moninaisuudesta kuitenkin seuraa, että tiukat rajaukset saattaisivat merkitä liiallista asian yksinkertaistamista. Olennaisinta lienee tässä vaiheessa se, ettei joitakin kieltenvälisiä vaikutuksia jätetä huomiotta vain siksi, että transfer alun perin kytkettiin behavioristiseen kielenoppimisteoriaan. Toisarvoista sinänsä on se, millä nimellä ilmiötä kutsutaan, vaikka transfer antaakin vaikutelman jonkin siirtämisestä, eikä sellaisesta aina ole kysymys. Varmaa on 
joka tapauksessa se, että kielten välistä vuorovaikutusta esiintyy, kun kielet ovat yhteydessä toisiinsa. Osa vuorovaikutuksesta on puhdasta 'siirtoa', mutta valtaosa on muuta kuin sitä. Mukana on myös ykköskielen vaikutuksen välttelyä, mikä aiheuttaa myös ongelmia. Terminologisesti olisi parempi puhua kielten välisestä vuorovaikutuksesta, mutta se ei vapauta meitä pohtimasta kysymystä, mistä tiedetään, milloin kyseessä on transfer.

Transferin syitä on monia (Dechert 1989: x-xii). Se voi merkitä tietoista lainaa kielestä toiseen: laina täyttää aukon, joka perustuu tiedon puutteeseen, silloin kun kieltä ei vielä osata tarpeellisessa määrin. Lainaaminen voi olla myös seurausta puutteellisuuksista kielen tuottamisen monitoroinnissa (Ringbom 1987: 50-52). Laina voi myös olla tahallisesti tuotettu vihje kielenkäyttäjän kielellisestä taustasta tai eri syistä tapahtuvaa kielellä leikittelyä. Kielen tuottamisprosessissa voi poikkeama johtua siitä, että kielen tuottaminen ohjautuu väärälle polulle esimerkiksi siksi, että kielessä ei ole saavutettu vielä tarpeellista taitotasoa tai tuottamisketjussa on tekijöitä, jotka johtavat harhaan. Kieltä vastaanottaessaan kielenkäyttäjä voi nojata tietoonsa äidinkielen järjestelmästä: hän ei 'kuule' toisen kielen yksiköitä sellaisina kuin ne ovat, vaan havainnot perustuvat ykköskielen järjestelmään.

Transfer on usein nähty yksioikoisesti kielen rakenteellisten elementtien 'siirtona', mutta kielenkäyttö on toki muutakin. Kielen merkitys on suuri kaikessa viestintää sisältävässä vuorovaikutuksessa. Sosiaaliset yhteisöt vaativat rakentuakseen kieltä välineeksi, eikä ihmisten kesken voi ajatella mielekästä toimintaa - lukuun ottamatta kaikkein yksinkertaisimpia askareita - ilman että heillä on käytössään kieli. Kieltä tarvitaan asioiden analysoimiseen ja analyysin tulosten välittämiseen edelleen. Näihin toimintoihin liittyvät taidot, sekä suulliset että kirjalliset, opitaan yleensä siinä sosiaalisessa yhteisössä, jossa välineenä on äidinkieli. Kun siirrytään muunkieliseen ympäristöön ja samanlaisiin tarpeisiin joudutaan vastaamaan siellä, käyttäytymisen opettelu ei ala suinkaan aivan alusta, vaan monet toiskielisen sosiaalisen yhteisön toiminnoista hallitaan jo. Sosiaalisiin käytänteisiin sisältyy runsaasti sellaista, mikä on tietoisen toiminnan tavoittamattomissa. Ihminen ei kovin hyvin pysty näkemään itseään, eikä välttämättä myöskään oman sosiaalisen yhteisönsä muita jäseniä, kulttuurisina käyttäytyjinä. Omaa kieltä ympäröivän maailman vaikutus ulottuu näin eri ympäristöissä esiintyvien diskurssien alueelle ja tavallaan koko toiseen kulttuuriin. Kulttuurien vertaaminen sellaisenaan ei kuitenkaan ole kovin hedelmällistä, jos kulttuurilla tarkoitetaan kokonaista kielellistä tai etnistä yhteisöä. Kuten Holliday (1999) toteaa, kulttuuri on lähempää tarkastelua vartenrajattava koskemaan 'pientä kulttuuria', missä pieni viittaa mihin tahansa kiinteään ryhmään tai yhtenäiseen toimintaan., koska muutoin päädytään tekemään tarpeettoman yksinkertaistavia yleistyksiä.

Kielenkäyttäjä on mukana lukuisissa kielenkäyttöyhteisöissä, joiden välille syntyy erilaisia kytkentöjä, mm. intertekstuaalisuuden ja interdiskursiivisuuden välityksellä. Nämä ilmiöt voivat olla myös kielirajat ylittäviä. Kielenkäyttäjän toiminta pohjautuu myös monenlaisiin taustoihin, jollaisia ovat esimerkiksi koulu, suku, yliopisto. Näiden kautta on kytkentöjä monenlaisiin kielenkäytön 
vakiintuneisiin muotoihin. Erilaiset taustatekijät määräävät, millaiset kielen yksiköt realisoituvat missäkin ympäristössä, millä taas on vaikutusta siihen, millaisia signaaleja voidaan jossakin ympäristössä odottaa toteutuviksi ja mitä siis missäkin ympäristössä pystytään tulkitsemaan. Tietty kulttuuri tai osakulttuuri luonnostaan tuottaa omanlaisiaan tekstejä. Näillä taas on vaikutusta myös siihen, miten erilaisen taustan omaavat kielenkäyttäjät virittäytyvät vastaanottamaan kyseisiä viestejä. Kontrastiivisen tutkimuksen tulisi ottaa huomioon erilaisten kielenkäyttöympäristöjen vaikutus, koska pelkkä muotojen tarkastelu ei ole riittävää tuomaan esiin vaikuttavia tekijöitä.

Transferiksi kutsuttua kielten välistä vuorovaikutusta kielen oppimisessa ja kielen käytössä ei vielä ole tutkittu tarpeeksi. Suuri osa siitäkin, mikä on olemassa, koskee lähinnä vain yksittäisten muotojen tai rakenteiden siirtoa kielestä toiseen. Yksittäisten rakenteellisten yksiköiden siirtyminen ykköskielestä toiseen kieleen riippuu oppimistapahtuman luonteesta ja kielenkäyttäjän tietoisesti tai tiedottomasti omaksumista, kielten välistä suhdetta koskevista odotuksista. Lisäksi vaikutusta siihen, mitä tapahtuu, on itse kunkin kielenkäyttäjän kokonaiskielivarannolla, siis sillä, millaisia kieliä ja missä määrin hän kaiken kaikkiaan hallitsee. Kyseessä on hyvin monisäikeinen keskinäisten vuorovaikutusten kimppu, ja jo siksi voidaan olettaa, ettei yhtäläistä käyttäytymistä voi olettaa kielenkäyttäjien kesken tai edes samalla kielenkäyttäjälläkään erilaisissa kielenkäyttötilanteissa tai -ympäristöissä. Lähes poikkeuksetta lienee joka tapauksessa kyse tiedon puutteesta tai osaamisen vajavaisuudesta tai kielellisten prosessien vika- tai vajaatoiminnasta (Sajavaara 1986: 71, 1987).

\section{$4 \quad$ Toisen kielen oppiminen}

Toisen kielen oppimisen teoriat voidaan jakaa karkeasti kolmeen pääryhmään: nativistiset, interaktiiviset ja sosiokulttuuriset (esim. Mitchell \& Myles 2004). Kolmekymmentä vuotta sitten, kun toisen kielen oppimisen tutkimus varsinaisesti alkoi, elettiin yleisesti chomskylaisuuden vaikutuspiirissä, mikä näkyi kielenoppimisen tutkimuksessa vahvoina käsityksinä, joiden mukaan kieli kasvaa ihmisessä universaalin kielikyvyn vaikutuksesta, kun hän vai joutuu kielelle alttiiksi. Seuraavaksi siirryttiin tarkastelemaan kieltä ihmistenvälisen vuorovaikutuksen tuloksena, ja sittemmin ilmiönä, joka perustuu ihmisen toimintaan ja oman identiteetin uusintaan hänen omassa ympäristössään (esim. Pavlenko \& Lantolf 2000). Näkökulmat kielenoppimiseen eivät ole toisiaan pois sulkevia, vaan käytännössä kielenoppimiseen voidaan katsoa sisältyvän ilmiöitä, joita voidaan perustella kaikilla kolmella näkökulmalla. Kielenoppimisen tarkastelussa tapahtunutta muutosta voisi kuvata siten, että kielenoppijaa ei enää nähdä pelkästään eräänlaisena mekanistisena laitteena, jonka läpi tietyt kielelliset rakennelmat syöttyvät, vaan hänen katsotaan olevan tavoitteellinen, toimiva ja inhimillinen olento (Pavlenko \& Lantolf 2002: 155). Samalla korostuu myös hänen sosiaalistumisensa ihmisyhteisön jäseneksi. Kielen oppimisessa ei ole ky- 
symys pelkästään kielen omaksumisesta, vaan myös oppimisesta kielen välityksellä (Halliday 1993). Kun hyväksytään tämä näkemys kielen oppimisesta, siitä seuraa, että oppimisesta tulee elinikäinen prosessi: ihminen oppii aina kun hän käyttää kieltä (de Bot et al.: 3).

Äidinkieli opitaan keskeisiltä osiltaan opettamatta, ja tuloksena on kielitaito, jota on totunnaisesti mutta epätarkasti kutsuttu täydelliseksi. Samanaikaisesti voidaan oppia myös useampia kuin yksi kieli ja tulla kaksi- tai monikieliseksi. Myöhemmin kieliä opitaan opettamatta tai opettamalla. Vilkasta keskustelua on aiemmin käyty siitä, tapahtuuko tällainen myöhempi oppiminen samanlaisten prosessien kautta kuin ykköskielen. Suurin osa tätä koskevasta pohdiskelusta koskee kuitenkin ainoastaan tiettyjen morfeemien oppimisen järjestystä (Mitchell \& Myles 2004: 47). Tiettyä samankaltaisuutta on ollut havaittavissa, mutta jo osattujen kielten vaikutus aiheuttaa poikkeamaa. Oppijan iällä on myös merkitystä. Ykköskieli opitaan ennen muodollisen koulutuksen alkamista, kun taas toinen kieli opitaan joko ennen muodollisen koulutuksen alkamista, sen aikana tai sen jälkeen. Äidinkielen oppijat ovat kognitiivisesti kypsymättömiä, mutta meiltä puuttuu tieto kognitiivisesti kypsistä ykköskielen oppijoista, koska tällaisia tapauksia tunnetaan vain muutama (tunnetuin ja tutkituin on lapsi nimeltä Genie, ks. Rymer 1994).

Voimakkain kehitys toisen kielen oppimisen tutkimuksessa alkoi 1970luvun lopulla Krashenin kirjoituksista (kokoava yhteenveto, esim. Krashen 1981; ks. myös Mitchell \& Myles 2004: 39-49). Hän esitti alun perin monitoriteoriaksi, sittemmin inputhypoteesiksi kutsumansa toisen kielen oppimisen hahmotelman, jonka keskeisenä ajatuksena oli luonnostaan tapahtuvan kielenomaksumisen (acquisition) ja muodollisessa opiskelussa tapahtuvan kielenoppimisen (learning) erottaminen toisistaan. Omaksuminen oli tiedostamatonta, se tapahtui epämuodollisessa ympäristössä, ja sen tuloksena oli 'tuntu' siitä, miten asioiden tuli kielessä olla; oppiminen taas oli tiedostettua, se tapahtui muodollisessa ympäristössä, ja sen perustana olivat kielestä johdetut säännöt. Omaksuminen noudatti morfeemien osalta säännöllistä järjestystä, kun taas oppiminen eteni yksinkertaisesta monimutkaiseen. Omaksumiseen vaikuttivat asenteet, oppimiseen kielilahjakkuus. Olennainen ja kaikkein eniten kiistaa herättänyt piirre hänen ajatuksissaan oli se, ettei muodollisesti opiskeltu tieto voinut koskaan muuttua omaksutuksi. Hänen mukaansa kaikki kielen tuottaminen alkoi omaksutulta pohjalta, ja opiskeltu ja näin opittu tieto oli käytettävissä ainoastaan omaksutun pohjalta alkaneen tuotosprosessin monitorointiin ja korjaamiseen.

Krashenin ajatukset herättivät vilkasta keskustelua ja runsaasti myös tutkimusta, joka oli myöhemmin virikkeenä vuorovaikutuspohjaiseen kielenoppimisen teoriaan. Erityisen voimakkaana pyöri keskustelu omaksumisen ja oppimisen eron ympärillä, koska Krashenillä ei katsottu olevan aineistoa väitteidensä tueksi. Kieltenopettajat hyväksyivät hänen näkemyksensä laajalti. Uudempi neurolingvistinen tutkimus on osoittanut, että eksplisiittinen, opiskeltu tieto ja implisiittinen, tiedostamaton tieto käyttävät eri reittejä ihmisen neurologisessa järjestelmässä ja oppimisessa on myös eroa näiden kahden tietovaran- 
non välillä (Paradis 1994), mutta toisaalta Krashenistä poikkeavasti näiden kahdenlaisen tietojärjestelmän välillä vallitsee myös kytkös.

Krasheniä seuranneessa keskustelussa on tullut esille koko joukko tekijöitä, joiden merkitystä toisen kielen oppimisen kannalta on pidetty tärkeänä. Krashen itse nosti esiin keskeisenä inputin, jonka hän arveli vievän kielenoppimista eteenpäin siten, että oppijaan kohdistuva kielen tarjonta vaikeutuu vähitellen oppimisen edetessä. Inputilla on varmasti oma osuutensa oppimisessa, mutta Krashenin ajatusten mukaista vaikeutumista ei kuitenkaan ole voitu havaita. Olennainen kysymys liittyykin siihen, miten inputista päästään kielen elementtien sisäistämiseen. Todennäköinen selitys on ilmeisesti osittain riippuvainen siitä, millaisten kielen yksiköiden olemassaolon oppija havaitsee ja miten hänen huomionsa kohdistuu niihin (Schmidt 1990). Oppijaan kohdistuvassa inputissa voidaan katsoa olevan erilaisia tarjokkaita (affordances), joista oppija erilaisilla perusteilla havainnoi niitä, joita tarvitsee kielen rakennukseksi, jos niihin kiinnittyy huomio joko tietoisesti tai tiedostamatta (van Lier 1996: 52-53). Kielenoppimisen kilpailumallin sovelluksessa on saatu konkreettista näyttöä tällaisten vaikutusten olemassaolosta (Kempe \& MacWhinney 1998). Oppijan tietoisuuden tasoa nostamalla voidaan vahvistaa hyödyllisiä kehityssuuntia. Keskittyminen muotoon luokkaopetuksessa merkitsee tietoisuuden lisäämistä ja inputin vahvistamista, mistä voi olla seurauksena opittavien asioiden näkyvyyden lisääntyminen.

Aivan selvää ei aina ole, millä perusteella oppija tekee oletuksiaan kielestä. Emme tiedä, miten kielen yksiköt ilmenevät oppijan mielessä. Missään tapauksessa kaikki osa-alueet eivät ole samanarvoisia tai samanlaisia, eivätkä kaikki varsinkaan ole samalla tavalla tiedostettavissa. Oletettavissa lisäksi on, että eri kielissä erilaisten kielen osa-alueiden painoarvo on tässä mielessä erilainen. Esimerkiksi englannin kielen puherytmi ja prosodia antavat aiheen olettaa, että yksittäisillä sanoilla on englannin prosessoinnissa erilainen asema kuin suomen kielessä, jossa puherytmi ja prosodia tuovat yksittäiset sanat selvästi paremmin esille. Toisen kielen oppijat ovat äidinkielensä kompetentteja käyttäjiä. Jokaisella on äidinkielessään kielitaito, joka riittää toimimiseen tutuissa tilanteissa, ja jokaisella on vähintäänkin intuitio siitä, miten ihmiset käyttävät kieltä, mihin he kieltä käyttävät, millaista kieltä he käyttävät ja millaista kieltä hän itse osaa/ei osaa/voi osata käyttää. Lisäksi jokaisella on kieltä ja kielen käyttöä koskevia oletuksia ja asenteita. Sosiaaliset käytänteet kulkevat tietyllä tavalla kielen käytänteiden edellä, koska juuri niiden kautta kielen käytänteet opitaan.

Muodollinen opetus lisää uusia ja todennäköisesti erilaisia oletuksia ja asenteita. Jotkin kieltä koskevat oletukset vahvistuvat, esimerkiksi siksi, että puhutun kielen rinnalle nousee yleensä myös kirjoitettu kieli kaikkine kirjalliseen kulttuurin liittyvine ilmiöineen. Koulutuksen antia on myös hyvän kielenkäytön käsite, joka ei liity kieleen sinänsä. Nousee myös uusia kulttuurisen vaikutuksen muotoja. Tietoisuuden merkitys kasvaa, ja samalla kielen käyttämiseen saattaa ilmaantua uudenlaista intentionaalisuutta. Kaikki kielenkäyttäjät eivät ole samalla tavalla tietoisia, koska kokemuspiiri on erilainen, millä on vai- 
kutusta myös kieleen kohdistuvan motivaation luonteeseen. Motivaation toiminnallinen perusta saattaa muuttua ratkaisevasti toisenlaiseksi.

Kielten etäisyydellä on oppimismielessä hyvin paljon merkitystä. Ringbom (1979: 81, 1987: 133-139) kiinnitti huomiota jo varhain siihen, että aloitteleva ruotsinkielinen englannin oppija osaa jo intuitiivisesti runsaasti englantia, koska hän pystyy oman kielensä perusteella hahmottamaan sanojen merkityksiä ja tulkitsemaan oikein kielen rakenteiden tehtäviä. Kielen oppimisen varhaisvaiheissa tästä on suuresti apua tarjolla olevan inputin hyödyntämisessä oppimisen tarpeisiin. Kyse on kuitenkin paljon laajemmasta ja monisäikeisemmästä ilmiöstä kuin sen toteaminen, että jokainen osaa jo luonnostaan jotakin kaikista muista kielistä. Kielenoppijahan ei välttämättä tiedä, mitä hän tietää tai mitä hän ei tiedä, ja siksi koko kysymys kääntyy ongelmaksi kielenoppijan kyvystä havaita todellisia tai oletettuja kielten väliseen etäisyyteen liittyviä ilmiöitä. Kielenoppijan ja kielenkäyttäjän havainto kielten välisestä etäisyydestä ei siis perustu niiden todelliseen etäisyyteen, vaan intuitiiviset ajatukset etäisyydestä voivat perustua hyvinkin monenlaisiin oletuksiin ja asenteisiin. Joissakin tapauksissa kielenkäyttäjä saattaa jopa torjua jonkin tavoitekielen hyväksyttävän ilmauksen siksi, että se on liian samankaltainen äidinkielen ilmauksen kanssa (Kellerman 1977). Merkitystä voi olla myös sillä, mihin kielen varianttiin (lapsena opittu kielimuoto, standardikieli, jokin muu) kielenkäyttäjä vastaavuusoletuksensa perustaa. Varhaisessa kontrastiivisessa tutkimuksessa kielten samankaltaisuudesta ei yleensä välitetty, vain erot olivat merkitseviä.

Ykköskielessä kielenkäyttäjälle kehkeytyy kaksi osaamisen aluetta. On olemassa kielen perusjärjestelmä, johon kuuluvat kielioppi ja ainakin osa sanastosta. Tämä perusjärjestelmä pohjautuu tiedostamattomasti omaksuttuun. Ulkopuolisilla ei sen muotoutumiseen juuri ole vaikutusta, vaan se rakentuu oppijan luonnollisessa kielenkäytössä sisäistämiin periaatteista. Ulkopuolelta voidaan välillisesti ohjata oppijaa suuntautumaan siten, että sisäisissä prosesseissa tapahtuu muutoksia. Myöhemmässä vaiheessa kehittyy muodollisen opetuksen kautta toinen järjestelmä, joka perustuu tietoisiin, analyyttisiin toimintoihin ja jota voidaan ohjata tietoisten strategioiden avulla siten, että oppija kiinnittää tietoisesti huomionsa joihinkin seikkoihin. Lisäksi oppijaa voidaan ulkopuolelta ohjata käyttämään tietoisia metalingvistisiä strategioita.

Perusjärjestelmä ei suinkaan ole vakaa ja muuttumaton, vaan muodollisen opetuksen kautta se voi kehittyä huomattavankin toisenlaiseksi kuin se on ollut alun perin. Muodollisen opiskelun eräänlainen korkea-aste saavutetaan kirjoitetun kielen opetuksen kautta: oppijan huomio kiinnittyy kielessä esiintyviin muotoseikkoihin ja hänelle annetaan mahdollisuus kielen rakenteiden, sanaston ja merkitysten 'hienostuneeseen' hallintaan. Kun usein sanotaan, ettei luokka ole oikea ympäristö luonnollisen kielenkäytön oppimiseen, voidaan aivan yhtä varmasti todeta, että se on erinomainen ympäristö tietoiseen kielenkäytön tutkiskeluun. Lukemisen taito saattaa olla välttämätön edellytys kakkoskielen kunnolliselle osaamiselle, koska toisen kielen hyvän hallinnan saavuttaminen vaatii useissa tapauksissa kognitiivista kypsyyttä, muodollista opetusta ja jonkinasteista älykkyyttä. 
Kakkoskielessä, ainakin aikuisilla, edellä mainitut kaksi kielen järjestelmää ovat olemassa. Aikuisella on käytettävänään kaksi tapaa oppia: tiedostamattomat prosessit ja tietoiset strategiat. Tiedostamattomat prosessit voivat liittyä mihin tahansa kielen ja kielenkäytön osa-alueeseen, kun taas tietoiset strategiat eivät ole käytettävissä kaikilla osa-alueilla. Kontrastiivinen kielten tarkastelu ei voi tukea kaikkea kakkoskielen kehitystä, koska on olemassa ilmiöitä, jotka on omaksuttava. Niilläkin alueilla saattavat aiemmin opittujen kielten järjestelmät aiheuttaa häiriöitä sekä kielen vastaanotossa että sen tuottamisessa. Kontrastiivinen pohdiskelu voi toimia inputia vahvistavana ja lisätä tietoisuutta kielen ilmiöistä tuomalla korostetusti esiin ykköskielestä poikkeavia kakkoskielen ilmiöitä ja osoittamalla tyypillisiä ykköskielen todennäköisesti aiheuttamia poikkeamia kakkoskielen ominaisuuksista. Säännöistä, joita kielenopetuksessa opetuskielestä annetaan, on syytä kuitenkin muistaa, että ne lähinnä kasvattavat juuri metalingvististä tietoutta. Psykolingvistiseltä kannalta kielioppisäännöt ovat liian pinnallisia, jotta niiden voisi ajatella toimivan luotettavasti aitojen kielellisten prosessien välikappaleina (Seliger 1979).

\section{$5 \quad$ Lopuksi}

Siirtymiä esiintyy kaikkien puhujan hallitsemien kielten kesken. Usein on kysymys lainaamisesta, ja syynä ovat joko tiedon puute tai prosessoinnin häiriöt. Siirtovaikutuksen osoittaminen on usein vaikeaa, erityisesti siksi, että tiedämme vielä kovin vähän siitä. miten kieli elää ihmisen mielessä. Pääosin se, mitä tiedämme, perustuu pelkkiin oletuksiin tai on ollut hankittavissa epäsuorasti.

Kielen oppijoiden ja kielen käyttäjien väliset yksilölliset eroavuudet ovat suuria, koska kielenoppimisen edistymiseen on vaikuttamassa kielissä itsessään olevien ainesten lisäksi suuri määrä erilaisia tekijöitä, jotka eivät ole kielellisiä (ks. esim. Block 2003: 126).

Syitä on siis erittäin runsaasti, miksi kontrastiivinen analyysi, sellaisena kuin sitä alun perin hahmoteltiin, ei ole voinut koskaan kunnolla päästä kielenopetusta palveleviin tavoitteisiin. Todennäköistä on, että tutkimus voi tällä alueella edetä nykytasolta vasta sitten, kun kielten vertailua harrastavat tutkijat luopuvat laajemmin ajattelemasta kielten välistä vuorovaikutusta pelkästään ahtaasti kielitieteellisenä ongelmana, niin yllättävältä kuin se ehkä kuulostaakin. Näin siksi, että kielten välinen vuorovaikutus tapahtuu kielen oppijan ja käyttäjän mielessä eikä siis kielten rakenteissa. Kokonaan oma kysymyksensä on vielä se, millainen kontrastiivinen tieto todella auttaa kielen oppijaa ja miten sellainen tieto olisi opetettava, jotta siitä olisi oppijalle hyötyä. 


\section{LÄHTEET}

Bialystok, E. 2001. Bilingualism in development: Language, literacy, and cognition. Cambridge: Cambridge University Press.

Block, D. 2002. 'McCommunication': a problem for SLA. Teoksessa Block, D. \& Cameron, D. (toim.) Globalisation and language teaching. London: Routledge, 117-133.

Block, D. 2003. The social turn in second language acquisition. Edinburgh: Edinburgh University Press.

Cenoz, J., Hufeisen, B. \& Jessner, U. (toim.) 2001. Cross-linguistic influence in third language acquisition: Psycholinguistic perspectives. Clevedon: Multilingual Matters.

Cook, V. 1995. Multicompetence and the learning of many languages. Language, Culture and Curriculum 8, 93-98.

de Bot, K., Lowie, W. \& Verspoor, M. 2005. Second language acquisition: An advanced resource book. London: Routledge.

Dechert, H. W. 1989. Introduction. Teoksessa Dechert, H.W. \& Raupach, M. (toim.) Transfer in language production, s. ix-xvii. Norwood, NJ: Ablex.

Fisiak, J.1971. The Polish-English contrastive project. Papers and Studies in Contrastive Linguistics 1, 7-13.

Fries, C. 1945. Teaching and learning English as a foreign language. Ann Arbor: University of Michigan Press,.

Gass, S. M. \& Selinker, L. (toim.) 1992. Language transfer in language learning. Uudistettu laitos. Benjamins, Amsterdam.

Hakulinen, A., Vilkuna, M., Korhonen, R., Koivisto, V., Heinonen, T.R. \& Aalto, I. 2004. Iso suomen kielioppi. Helsinki: Suomalaisen Kirjallisuuden Seura.

Haugen, E. 1953. The Norwegian language in America: A study of bilingual behaviour 1-2. Philadelphia: University of Pennsylvania Press.

Halliday, M.A.K. 1975. Learning how to mean. London: Arnold.

Halliday, M.A.K. 1993. Towards a language-based theory of learning. Linguistics and Education 5, 93-116.

Holliday, A. 1999. Small cultures. Applied Linguistics 20: 2, 237-264.

Jarvis, S. 2000 Methodological rigor in the study of transfer: Identifying L1 influence in the interlanguage lexicon. Language Learning 50: 2, 245-309.

Jessner, U. 1999. Metalinguistic awareness in multilinguals: Cognitive aspects of third language learning. Language Awareness 8: 3-4, 201-209.

Kellerman, E. 1977. Towards a characterisation of the strategy of transfer in second language learning. Interlanguage Studies Bulletin 2, 138-145.

Kellerman, E. \& Sharwood Smith, M. (toim.) 1986. Crosslinguistic influence in second language acquisition. Oxford: Pergamon Press.

Kempe, V. \& MacWhinney, B. 1998. The acquisition of case marking by adult learners of Russian and German. Studies in Second Language Acquisition 20: 4, 543-587. 
Krashen, S. D. 1981. Second language acquisition and second language learning. Oxford:Pergamon.

Kupferberg, I. 1999. The cognitive turn of contrastive analysis: Empirical evidence. Language Awareness 8, 210-222.

Kühlwein, W. 1990. Language processes in contrast. Michaux, A., Sinner, A. \& Weber, J.J. (toim.). English studies 2, Luxembourg: Cercle Universitaire du Luxembourg, 63-108.

Lado, R. 1957. Linguistics across cultures. Ann Arbor: University of Michigan Press.

Lantolf, J. P. (toim.) 2000. Sociocultural theory and second language learning. Oxford: Oxford University Press.

MacWhinney, B. \& Bates, E. 1989. The crosslinguistic study of sentence processing. Cambridge: Cambridge University Press.

Mitchell, R. \& Myles, F. 2004. Second language learning theories. 2. laitos. London: Arnold.

Odlin, T. 1989. Language transfer: Crosslinguistic influence in language learning. Cambridge: Cambridge University Press.

Paradis, M. 1994. Neurolinguistic aspects of implicit and explicit memory: Implications for bilingualism and SLA. Teoksessa Ellis, N. (toim.) Implicit and explicit learning of languages. London: Academic Press, 393-420.

Pavlenko, A. 1999. New approaches to concepts in bilingual theory. Bilingualism 2, 209-230.

Pavlenko, A. \& Lantolf, J.P 2000. Second language learning as participation and (re)construction of selves. Lantolf, J.P. (toim.) Sociocultural theory and second language learning. Oxford: Oxford University Press, 155-177.

Pavlenko, A. \& Jarvis, J. 2002. Bidirectional transfer. Applied Linguistics 23: 2, 190-214.

Ringbom, H. 1979. The English of Finns, Swedes and Swedish Finns: Some concluding remarks. Palmberg, R (toim.) Perception and production of English: Papers on interlanguage. AFTIL 6, Department of English. Åbo: Åbo Akademi, 77-85.

Ringbom, H. 1987. The role of the first language in foreign language learning. Clevedon, Avon: Multilingual Matters.

Rymer, R. 1994. Genie: A scientific tragedy. Harmondsworth: Penguin.

Sajavaara, K. 1977. Contrastive linguistics past and present and a communicative approach. Sajavaara, K. \& Lehtonen, J. (toim.) Contrastive papers. Jyväskylä Contrastive Studies 4. Jyväskylä: Jyväskylän yliopisto, 9- 30

Sajavaara, K. 1981. Psycholinguistic models, second-language acquisition and contrastive analysis. Teoksessa Fisiak, J. (toim.). Contrastive linguistics and the language teacher. Oxford: Pergamon Press, 87-120

Sajavaara, K. 1986. Crosslinguistic influence in second language acquisition. Teoksessa Kellerman, E. \& Sharwood Smith, M. (toim.) Crosslinguistic influence in second language acquisition. Oxford: Pergamon Press, 66-79. 
Sajavaara, K. 1987. Second language speech production: Factors affecting fluency. Teoksessa Dechert, H. W. \& Raupach, M. (toim.). Psycholinguistic models of speech production, 45-65.

Sajavaara, K. 1999. Kontrastiivinen kielentutkimus ja virheanalyysi. Teoksessa Sajavaara, K. \& Piirainen-Marsh, A. (toim.) Kielenoppimisen kysymyksiä. Jyväskylä: Soveltavan kielentutkimuksen keskus, 103-128.

Seliger, H. W. 1979. On the nature and function of language rules in language teaching. TESOL Quarterly 13: 3, 359-369.

Schmidt, R. W. 1990. The role of consciousness in second language learning. Applied Linguistics 11: 2, 129-158.

Sjöholm, K. 1995. The influence of crosslinguistic, semantic and input factors on the acquisition of English phrasal verbs. A comparison between Finnish and Swedish learners at an intermediate and advanced level. Åbo: Åbo Akademi University Press.

Spada, N. \& Lightbown, P. 1999. Instruction, first language influence, and developmental readiness in second language acquisition. Modern Language Journal 82:1, 1-22.

van Lier, L. 1996. Interaction in the language curriculum. London: Longman.

Weinreich, U. 1953. Languages in contact. Publications of the Linguistics Circle of New York 1. New York: The Linguistics Circle.

Viitekehys 2003 = Kielten oppimisen, opettamisen ja arvioinnin yhteinen eurooppalainen viitekehys. Helsinki: WSOY. 